\title{
THE SEARCH FOR CONSENSUS AND UNANIMITY WITHIN THE INTERNATIONAL ORGANIZATIONS
}

\author{
Christian Guillermet Fernández ${ }^{*}$ \& David Fernández Puyana ${ }^{* *}$
}

Consensus is a process of non-violent conflict resolution. Everyone works together to make the best possible decision for the group. All concerns are raised and addressed, until all voices are heard. Since proposals are not the property of the presenter, a solution can be made cooperatively. Reaching consensus on a proposal does not mean that, everyone is in agreement ${ }^{1}$. Consensus decision making is a creative and dynamic way of reaching agreement between all members of a group. Instead of simply voting for an item and having the majority of the group getting their way, a group using consensus is committed to finding solutions that, everyone actively supports, or at least can live with. At the heart of consensus is a respectful dialogue between equals. It is about helping groups to work together to meet both the individual's and the group's needs. Consensus is looking for "win-win" solutions that are acceptable to all, with the direct benefit that everyone agrees with the final decision, resulting in a greater commitment to actually turning it into reality. Consensus seeks to synthesize the wisdom of the group unity: everyone has a piece of the truth $^{2}$. The recent adoption by 195 States of the "Paris Agreement" in the context of the 2015 United Nations Climate Change Conference is a "good example" of consensus.

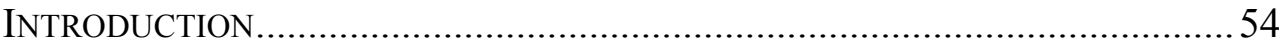

I. HiSTORICAL RoOTS OF CONSENSUS DECISION MAKING ......................... 54

II. The Rule of UnANimity In ThE PRACTICE OF THE LEAGUE OF NATIONS56 III. APPROACH TO CONSENSUS BUILDING WITHIN THE UNITED NATIONS .....58

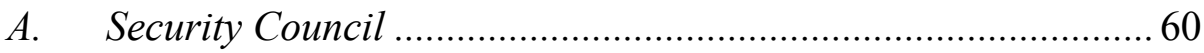

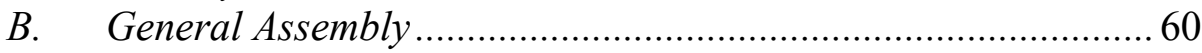

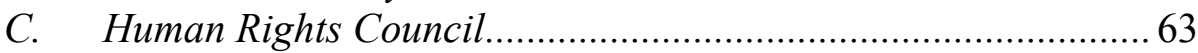

D. Other Intergovernmental Bodies, United Nations Agencies and

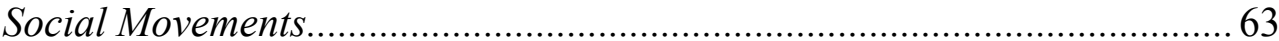

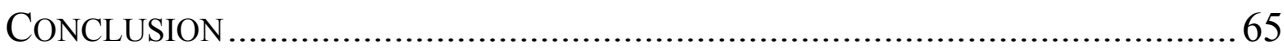

\footnotetext{
${ }^{*}$ Chairperson-Rapporteur of the first, second and third sessions of the Open Ended Working Group on the Right to Peace and Vice-Director General for Foreign Policy at the Ministry of Foreign Affairs of Costa Rica. Research fields: human rights, peace and development.

** BA, LLM, PhD, legal assistant of the Chairperson-Rapporteur. Research fields: human rights, peace and development.

${ }^{1}$ Guillermet Fernandez C., \& Fernandez Puyana D., The 70 Anniversary of the Creation of the United Nations: Giving Peace a Chance, 2(4) CADMUS 26 (State of California (USA): World Academy of Art and Science, April 2015).

${ }^{2}$ Guillermet Fernandez C., \& Fernandez Puyana D., op. cit. 1, 27.
} 


\section{INTRODUCTION}

This paper will analyse the historical roots of consensus decision making. In particular, the elaboration of this type of decision making process by the three main religions (i.e. Christian, Muslim and Jewish) and indigenous peopleswill carefully be analysed. Both the Haudenosaunee Confederacy and the Hanseatic League decisively influenced this approach in some legal systems.

Additionally, an assessment about the rule of unanimity accepted by the League of Nations will also studied, in the context of the debate about the efficiency of this rule held at the Permanent Court of International Justice and the Hague Conference for the Codification of International Law. They concluded that, resolutions or instruments on questions affecting the well-being of humankind as a whole could not be adopted against the will of some other States.

Finally, a reflection about consensus building within the United Nations, and in particular the Security Council, the General Assembly and the Human Rights Council will be provided, concluding with an emphasis that, the adoption of resolutions by consensus is the clear tendency and practice at the United Nations. In fact, some intergovernmental organizations, specialized agencies and social movements have expressly accepted consensus in their respective rules of procedures and have also concluded that, the term "consensus" refers to an established practice under which every effort is made to reach without vote an agreement that is generally accepted.

\section{HistoricAl RoOTS OF CONSENSUS DECISION MAKING}

One of the most widely cited historical roots for consensus decisionmaking is the Quakers traditions and to a lesser extent, the Anabaptists of which perhaps the best known descendents are the Mennonites ${ }^{3}$.

Consensus as a decision-making formula has served the Jewish communal system throughout much of the 20th century. In understanding the term "consensus", we find the following core definition: "the collective opinion by most of those concerned." Rela Mintz Geffen, in 1997, acknowledged that, consensual decision-making was one of the core "constitutional principles" that served to define the Jewish experience in

\footnotetext{
${ }^{3}$ See Available at $\mathrm{https}: / /$ rhizomenetwork.wordpress.com/2011/06/18/a-brief-history-of-consenusdecision-making/.
} 


\section{THE SEARCH FOR CONSENSUS AND UNANIMITY55}

America ${ }^{4}$.

Ijmā is an Arabic term referring to the consensus or agreement of the Muslim community basically on religious issues. Various schools of thought within Islamic jurisprudence may define this consensus to be that of the first generation of Muslims only; or the consensus of the first three generations of Muslims; or the consensus of the jurists and scholars of the Muslim world, or scholarly consensus; or the consensus of all the Muslim world, both scholars and laymen ${ }^{5}$.

Another common reference in the quest for consensus decisionmaking's heritage are indigenous peoples. Many peoples from different parts of the globe are cited. The Haudenosaunee Confederacy are frequently mentioned (sometimes referred to as the Iroquois League - the name given to them by the French). The confederacy still exists today ${ }^{6}$.

In 1987, the U.S. Senate formally acknowledged, in a special resolution, the influence of the Haudenosaunee Great Law of Peace on the U.S. Constitution, as follows:

"Acknowledges the historical debt of the United States to the Iroquois Confederacy, and other Indian nations for their demonstration of democratic principles and their example of a free association of independent Indian nations".

Other indigenous peoples are quoted as using consensus, for example African Bushmen. Usually, this seems to be defined as a system of decisionmaking in which a council of elders makes decisions based on a consensus of the wider community ${ }^{8}$. This form of decision making process still is applied in many African countries.

The Hanseatic League is another example of a group that utilizes strong elements of what we understand to be consensus in their governance structure. The League was "an economic alliance of trading cities and their merchant guilds that dominated trade along the coast of Northern Europe. It stretched from the Baltic to the North Sea and inland during the Late Middle Ages and early modern period (c. 13th-17th centuries)" $"$.

\footnotetext{
${ }^{4}$ Windmueller S., Consensus as a Symbol of Jewish Citizenship, SH'MA 5 (October 2003).

${ }^{5}$ Omar Farooq M., The Doctrine of Ijma: Is There a Consensus? (2006).

${ }^{6}$ National Museum of the American Indian, Haudenosaunee Guide for EduCATors 3 (Smithsonian Institution 2009).

${ }^{7}$ Senate Resolution 76-100th Congress, (1987-1988).

${ }^{8}$ Hitchcock R. K., Communities and Consensus: An Evaluation of the Activities of the Nyae Nyae Development Foundation and the Nyae Nyae Farmers Cooperative in Northeastern Namibia, NYAE Nyae Development Foundation And New York (New York, Windhoek, Namibia: Ford Foundation 1992).

${ }^{9}$ Windmueller S., Consensus as a Symbol of Jewish Citizenship, SH’MA, 5 (October 2003).
} 
The European Union follows the historical example of the Diet of the Hanseatic League about the rule of consensus ${ }^{10}$. In particular, Art. 16.4 of the European Union's Treaty of Lisbon decrees that, "except where the Treaties provide otherwise, decisions of the European Council shall be taken by consensus".

\section{The RUle of UnANimity In THE PRACTICE OF THE LEAGUE OF NATIONS}

The Hague Peace Conferences supported the traditional doctrine of unanimity, but disguised them "by the fiction of quasi-unanimity", which recognized as unanimously accepted a proposal receiving a substantial majority of the votes cast. Certain proposals of the Proceedings of the First Hague Conference were adopted unanimously with the exception of two votes - United States and Great Britain — and one abstention — Portugal__"11.

At the close of World War I, the Treaty of Versailles established the League of Nations which stipulates in Article 5 of its Covenant, the unanimity rule for all decisions of the Council or Assembly except as otherwise expressly provided in the Covenant. Consequently, voting in the League of Nations was normally based on the so-called unanimity rule ${ }^{12}$.

Under the League Covenant, the Council was governed by the unanimity rule except in procedural matters, and this proved a serious handicap, particularly when the Council was acting under Article 11 of the Covenant. It was possible for a member of the Council, accused of threatening or disturbing the peace, to prevent any effective action under this Article by the interposition of its veto, as happened in the case of Japanese aggression in Manchuria in 1931, and the threat of Italian aggression in Ethiopia in $1935^{13}$.

The Permanent Court of International Justice stated that, the rule of unanimity was "in accordance with the unvarying tradition of all diplomatic meetings or conferences" and noted that, in the Council of the League, "observance of the rule of unanimity is naturally and even necessarily indicated" $" 14$.

Additionally, the Permanent Court also added in regards to the organs

\footnotetext{
${ }^{10}$ Miller P., Vandome A. F., \& J. Mcbrewster J., Consensus Decision Making (Alphascript Publishing 2009)

${ }^{11}$ Jessup P. C., Parliamentary Diplomacy, 89(I. 13) ReCueIl Des Cours, official review from the International Law Academy 242 (1956).

${ }^{12}$ Rosenne, SH., United Nations Treaty Practice, 86(II) ReCuEIL Des Cours 312 (1954).

${ }^{13}$ Goodrich, L. M., From League of Nations to United Nations, 1(1) InTERNATIONAL OrGanizATION, 11 (Feb. 1947).

${ }^{14}$ Advisory Opinion concerning Article 3, Paragraph 2, of the Treaty of Lausanne (Frontier between Turkey and Iraq), B(12) 29-30 (1925).
} 


\section{THE SEARCH FOR CONSENSUS AND UNANIMITY57}

of the League of Nations that, "in a body constituted in this way, whose mission is to deal with any matter within the sphere of action of the League or affecting the peace of the world, observance of the rule of unanimity is naturally and even necessarily indicated .... Moreover, it is hardly conceivable that, resolutions on questions affecting the peace of the world could be adopted against the will of those amongst the members of the Council who, although in a minority, would, by reason of their political position, have to bear the larger share of the responsibilities and consequences ensuing therefrom"15.

When the Hague Conference for the Codification of International Law met in 1930, the President of the Conference (Heemskerk, the Netherlands) stated that, "we should maintain the principle that, we must adopt unanimous resolutions and that unless we do so, we cannot have any codification of international law" ${ }^{16}$. On the other hand, While Politis (Greece) agreed that, "it was undoubtedly the wish of all to take unanimous decisions and also added that, no State or minority group of States will be permitted at this Conference to prevent the majority from embodying the results of its deliberations in a diplomatic instrument" ${ }^{\prime 17}$.

Proponents of consensus and unanimity consider it to have many advantages over majority voting, because it cultivates discussion, participation and responsibility, and avoids the so-called "tyranny of the majority". However, the drawback is a lengthy and difficult decision making process ${ }^{18}$.

The so-called unanimity rule has been much criticized. Critics often tend to lose sight of that fact that, the League was an association of independent states and must proceed by the way of unanimous compromise and not by majorities imposing decisions on minorities. No state today will put itself in the position of being legally compelled to take action or commit its national policy by a vote of foreign powers ${ }^{19}$.

A text is said to be adopted by consensus when all the members of the organ tasked with taking the decision give their tacit consent. No voting takes place. Consensus differs from unanimity which is an explicit agreement, resulting from a vote in which all members cast a vote. In

\footnotetext{
${ }^{15}$ Publications of the Permanent Court of International Justice, B (12), 29.

${ }^{16}$ Acts of the Conference for the Codification of International Law, Plenary MeETingS, L.N. Doc. C. 351.M.145.1930.V.14, at 21 (1930).

${ }^{17}$ Op. cit., at 16.

${ }^{18}$ Mossel E., \& Tamuz O., Making Consensus Tractable, Google Europe Fellowship IN Social COMPUTING 1 (October 2013).

${ }^{19}$ Howard-Ellis C., The Origin, Structure \& Working of the League of Nations, 124-125 (Boston: Houghton Mifflin Company 1929).
} 
summary: a consensus is obtained without voting when no one opposes the decision, and unanimity is when everyone agrees and votes in favour of the text.

\section{APPROACH TO CONSENSUS BUILDING WITHIN THE UNITED NATIONS}

The main change introduced into the United Nations since 1945 was the abolition of the unanimity rule and the decentralization and dissipation of the functional competence, through various organs, with a residuary and coordinating power of control in the General Assembly's exclusive competence over the United Nations budget ${ }^{20}$.

The substitution of majority decisions for unanimity in the drafting of international conventions will have far-reaching consequences. This issue was discussed by the General Assembly in its fifth and sixth session on the subject of reservations to multilateral conventions, and it also relevant that, the International Court of Justice has drawn its attention to this aspect as follows:

"The majority principle, while facilitating the conclusion of multilateral conventions, may also make it necessary for certain States to make reservations" 21 .

If the unanimity rule in the past led to a tendency to overplay the unattainable high standard, which had as a consequence that, agreements could be watered-down by representing the minimum to which all States would or could agree, the abolition of unanimity was perceived as an example of progress and democracy. However, this abolition led to other consequences, such as, firstly, it did not make easier the work to draft worth-while conventions having universal effects and secondly, it resulted in a multiplication of reservations going to the root of the agreements. Consequently, the question raised is whether the price of the abolition of unanimity was not too high ${ }^{22}$.

As was the practice prior to the First World War, the text of a multilateral convention has to be adopted by unanimity. Unanimous consent as regards the admissibility of reservations was the logical concomitant of the unanimity rule applying to the establishment of the text of multilateral conventions ${ }^{23}$.

In the context of a proposal (E/CN.9/L. 110) on the rules of procedure

\footnotetext{
${ }^{20}$ Rosenne SH., United Nations Treaty Practice, 86(II) ReCueIL Des Cours 313 (1954).

${ }^{21}$ Reservation Case, REPORTS 1951, 22 (I.C.J.).

${ }^{22}$ Rosenne SH., United Nations Treaty Practice, 86(II) ReCueIL Des Cours 313 (1954).

${ }^{23}$ Sinclair I., The Vienna Convention on the Law of Treaties, 56 (Manchester University Press 1984).
} 


\section{THE SEARCH FOR CONSENSUS AND UNANIMITY59}

of the World Population Conference, the President of the Conference wanted to know whether the decisions on important matters related to the substance should be adopted, if possible, by consensus.

In 1974, the Director of the General Legal Division at the Office of UN Legal Affairs made a statement about the use of the term consensus in the United Nations practice in the following terms ${ }^{24}$ :

"No plenipotentiary conference under United Nations auspices had included in its rules of procedure a provision on consensus, partly due to the fact that it was somewhat difficult to arrive at an exact definition of consensus, and partly because the objective which was usually sought, namely, that every effort should be made to achieve a consensus before a vote was taken, could better be achieved by simply an understanding at the beginning of the conference. In United Nations organs, the term 'consensus' was used to describe a practice under which every effort is made to achieve unanimous agreement; but if that could not be done, those dissenting from the general trend were prepared simply to make their position or reservations known and placed on the record".

The consensus system assures that, decision-making as a multilateral negotiation of a legal instrument will not be dominated by the numerical superiority of any group of nations. Since it is difficult to obtain acceptance of voting systems that, overtly recognize the differences in nations' importance, the consensus approach permits the maintenance of an egalitarian procedure which in practice may assure that, multilateral negotiations reflect the real geopolitical power of the participating nations ${ }^{25}$.

It follows that, consensus decision making is "an attempt to achieve an agreement of all the participants in a multilateral conference without the need for a vote and its inevitable divisiveness" ${ }^{26}$. In other words, it is an agreement of all taken unanimously by means other than voting and consequently, "the effort to achieve consensus ... protects the interests of those who risk becoming permanent minorities at each institution" 27 .

Consensus decision making as a mode of procedure became popular in the 1970 s, as a result of the growing number of independent states taking an active part in international politics. These large number of independent states were welcomed to take part in the international organizations through the encouragement of an "international governance of many" or

\footnotetext{
${ }^{24}$ Summary of a statement made at the 311th meeting of the Population Commission, on March 6, 1974.

${ }^{25}$ Buzan B., Negotiating by Consensus: Developments in Technique at the United Nations Conference on the Law of the Sea, 75 THE AMERICAN JOURNAL OF INTERNATIONAL LAW 327 (1981).

${ }^{26}$ Berridge G. R., Diplomacy: Theory and Practice 24 (3rd ed., Basingstoke: Palgrave Macmillan 2005).

${ }^{27}$ Kahler M., Leadership Selection in the Major Multilaterals, 24 (Washington: Institute for International Economics 2001).
} 
multilateralism which was linked with the principle of "the sovereign equality of states" 28 .

\section{A. Security Council}

Since the three vetoes by Russia and China over Syria in 2011 and 2012, and the inability of the Security Council to find a solution to the conflict, there has been a common perception that the Council is divided. Likewise, following the war in Iraq in 2003, the Council was viewed as having become badly fractured. However, looking at decisions adopted, the Council is actually divided on just a limited number of issues and otherwise largely operates by consensus ${ }^{29}$.

Presidential statements require consensus, and press statements are issued only with the agreement of all 15 members. All sanctions committees, with a few exceptions, and working groups also operate by consensus. Resolutions, which are put to a vote, are the only Council outcome that can be adopted with or without the unanimity of the Council. Most resolutions, however, have been adopted by consensus: 93.5 percent of those adopted since 2000 to December 15, 2013. Contrary to public perceptions, this is a noticeable increase from 88.9 percent in the 1990s, a period when the Security Council was viewed as highly active, and comparatively more effective and less divided due to the end of the Cold $\mathrm{War}^{30}$.

Consensus in Council decision-making seems to be the preferred mode even during years that generated bitter feelings among members. Despite recent divisions on Syria or prior to and following the 2003 Iraq war, consensus resolutions during these periods still prevailed at levels above 92 percent. Thus, it seems that, either the Council looks at the merits of each situation instead of allowing divisions on specific issues to permeate into its other work, or it makes a more concerted effort to at least appear united on other fronts ${ }^{31}$.

\section{B. General Assembly}

Each of the 193 Member States in the Assembly has one vote. Votes

\footnotetext{
${ }^{28}$ Kahler M., Multilateralism with Small and Large Numbers, Multilateralism MATTERs: THE TheORY AND PRAXIS OF AN InSTITUTIONAL Form 295 (J. Ruggie ed., New York: Columbia University Press 1993).

${ }^{29}$ In Hindsight: Consensus in the Security Council, SECURITY COUNCIL REPORT (New York, January 2014).

${ }^{30}$ In Hindsight: Consensus in the Security Council, SECURITY CounCIL REPORT (New York, January 2014).

${ }^{31}$ Op. cit. 30.
} 


\section{THE SEARCH FOR CONSENSUS AND UNANIMITY61}

taken on designated important issues - such as recommendations on peace and security, the election of the Security Council and Economic and Social Council members, and budgetary questions - require a two-thirds majority of Member States, but other questions are decided by simple majority ${ }^{32}$.

During the Cold War, the United Nations was very divided, and it was difficult for resolutions to pass with more than $60 \%-70 \%$ support of the members. Following the end of the Cold War, the United Nations has increasingly tried to work toward consensus, where many resolutions are adopted unanimously by all voting members. In recent years, an effort has been made to achieve consensus on issues, rather than deciding by a formal vote, thus strengthening support for the Assembly's decisions.

Additionally, it should be noted that, the rule of consensus has been included in the Rules of Procedure of the General Assembly in its Article 104 with regards to financial issues, as follows:

"The Special Committee considers that, the adoption of decisions and resolutions by consensus is desirable when it contributes to the effective and lasting settlement of differences, thus strengthening the authority of the United Nations. It wishes, however, to emphasize that, the right of every Member State to set forth its view in full must not be prejudiced by this procedure".

Unlike decisions regarding treaties and conventions, in which the system of reservations is applied by States, the adoption by consensus of Declarations on peace matters by the General Assembly has been a clear tendency since the creation of the United Nations.

In particular, it should also be recalled that, the Declaration on the Promotion among Youth of the Ideals of Peace, Mutual Respect and Understanding between Peoples of 1965, the Declaration on the Protection of Women and Children in Emergency and Armed Conflict of 1974, Declaration on the Participation of Women in Promoting International Peace and Co-operation of 1982 and the Political Declaration on the peaceful resolution of conflicts in Africa of 2013, were adopted by consensus. Neither the Declaration on Preparation of Societies for Life in Peace of 1978, the Declaration on the Right of Peoples to Peace of 1984 nor the Declaration and Programme of Action on a Culture of Peace of 1999 were adopted by the General Assembly with the opposition of regional groups.

Finally, it should also be noted that, most of Declarations, Rules and Guidelines on human rights adopted by the General Assembly since 1945 were adopted by consensus. In particular, the General Assembly has adopted around thirty Declarations in different fields of human rights, such as

\footnotetext{
${ }^{32}$ See Available at http://www.un.org/en/ga/about/background.shtml.
} 
children rights, racial discrimination, persons with disabilities, women, enforced disappearance, development, among others, after all different regional groups reached relevant agreements ${ }^{33}$. Only three important Declarations on human rights were adopted with some opposition, such as Declaration on the Right to Development ${ }^{34}$ or Indigenous Peoples ${ }^{35}$, or abstentions, such as the Universal Declaration of Human Rights ${ }^{36}$. But the rest of Declarations have been adopted by consensus.

Most of the declarations contain political statements only and thus have no binding effect in international law. However, the General Assembly has often adopted declarations which, although non-binding, have influenced the development of international law or in some cases have been regarded as reflecting customary law on the relevant topic. For this reason, the consensus or unanimity in the decision making process within the General Assembly has been critical in order to advance international law, and reflect

\footnotetext{
${ }^{33}$ Declaration of the Rights of the Child, United Nations Declaration on the Elimination of All Forms of Racial Discrimination; Declaration on the Promotion among Youth of the Ideals of Peace, Mutual Respect and Understanding between Peoples; Declaration on the Elimination of Discrimination against Women; Declaration on the Rights of Mentally Retarded Persons; Declaration on the Protection of Women and Children in Emergency and Armed Conflict; Declaration on the Rights of Disabled Persons; Declaration on the Protection of All Persons from Being Subjected to Torture and Other Cruel, Inhuman or Degrading Treatment or Punishment; Political declaration on Africa's development needs; United Nations Declaration on Human Rights Education and Training; Political declaration of the high-level meeting of the General Assembly to commemorate the tenth anniversary of the adoption of the Durban Declaration and Programme of Action "United against racism, racial discrimination, xenophobia and related intolerance"; Political declaration of the High-level Meeting of the General Assembly on the Prevention and Control of Non-communicable Diseases; Political Declaration on the peaceful resolution of conflicts in Africa; Basic Principles and Guidelines on the Right to a Remedy and Reparation for Victims of Gross Violations of International Human Rights Law and Serious Violations of International Humanitarian Law; Political Declaration on HIV/AIDS; Body of Principles for the Protection of All Persons under Any Form of Detention or Imprisonment; United Nations Guidelines for the Prevention of Juvenile Delinquency (The Riyadh Guidelines); United Nations Rules for the Protection of Juveniles Deprived of Their Liberty; Basic Principles for the Treatment of Prisoners, The protection of persons with mental illness and the improvement of mental health care; Declaration on the Rights of Persons belonging to National or Ethnic, Religious and Linguistic Minorities; Declaration on the Protection of All Persons from Enforced Disappearance; Standard rules on the equalization of opportunities for persons with disabilities; Declaration on the Elimination of Violence against Women; Declaration on the Right and Responsibility of Individuals, Groups and Organs of Society to Promote and Protect Universally Recognized Human Rights and Fundamental Freedoms; Declaration and Programme of Action on a Culture of Peace; Millennium declaration; United Nations Declaration on the New Partnership for Africa's Development; Declaration of Basic Principles of Justice for Victims of Crime and Abuse of Power; Declaration on Social and Legal Principles relating to the Protection and Welfare of Children, with special reference to Foster Placement and Adoption Nationally and Internationally; Declaration on the Elimination of All Forms of Intolerance and of Discrimination Based on Religion or Belief.

${ }^{34} 1$ Vote against and 8 Abstentions.

${ }^{35} 4$ Vote against and 11 Abstentions.

${ }^{36} 8$ Abstentions.
} 


\section{THE SEARCH FOR CONSENSUS AND UNANIMITY63}

the existence of a particular customary law among all States.

\section{Human Rights Council}

In accordance with Article 4 of the Rules of Procedure, the Council applies the rule of majority of votes for the adoption of resolutions and decisions. However, it should also recalled that, the "United Nations Human Rights Council: Institution-Building" ${ }^{37}$ establishes that, the search for consensus plays an important role in the negotiation process. In particular, Article 127 indicates that:

"The sponsors of a draft resolution or decision should hold open-ended consultations on the text of their draft resolution(s) or decision(s) with a view to achieving the widest participation in their consideration and, if possible, achieving consensus on them".

Consensus in the decision-making process has had an important effect in the works of the Council since its inception. Most of resolutions are adopted by consensus, representing around $82 \%$ of the totality of them.

The most controversial resolutions are those related to country situation, notably, Belarus, Syria, Israeli settlements in the Occupied Palestinian Territory, right of the Palestinian people to self-determination, Iran, NorthKorea, the occupied Syrian Golan.

Additionally, the Council has widely worked on topics, which have not been supported by all Council members, such as foreign debt, right of peoples to peace, international solidarity, integrity of the judicial system, non-repatriation of funds of illicit origin, the promotion of a democratic and equitable international order, the use of remotely piloted aircraft or armed drones in counter-terrorism and military operations, promotion and protection of human rights in the context of peaceful protests, unilateral coercitive measures, right to development, mercenaries and sexual orientation and gender identity.

\section{Other Intergovernmental Bodies, United Nations Agencies and Social Movements}

In the disarmament affairs, all resolutions are adopted by consensus. In fact, in the rules of procedure of the Conference of Disarmament, the rule of consensus is compulsory for the adoption of resolutions.

\footnotetext{
${ }^{37}$ UNGA Resolution 5/1, Institution-BUILDING OF THE UNITED NATIONS HuMAN Rights COUNCIL (June 18, 2007).
} 
In addition, many conventions and treaties on disarmament operate through the rule of consensus among all countries. In particular, the Chemical Weapons Convention specifies in its Article 18 that, "... decisions on matters of substance should be taken as far as possible by consensus". In addition, the Anti-Personnel Mine Ban Convention regulates in Article 6 that, "... the Meeting of the States Parties or the Special Meeting of the States Parties shall make every effort to reach a decision by consensus". The Arms Trade Treaty also indicates in Article 17.2 that, "the Conference of States Parties shall adopt by consensus its rules of procedure at its first session". Finally, the Rarotonga, Pelindaba and Bangkok treaties also specify that decisions shall be taken by consensus.

The principle of consensus has been adopted by the Association of South East Asian Nations (ASEAN), Executive Committee of International Monetary Fund (IMF), General Agreement on Tariffs and Trade (GATT) and World Trade Organization (WTO), North Atlantic Treaty Organization (NATO) and Organization for Security and Cooperation in Europe $(\mathrm{OSCE})^{38}$.

It should be noted the extension of the International Labour Organization (ILO) system to certain of the Specialized Agencies, which expressly rejected the decision-making process adopted by the United Nations $^{39}$. It is significant to stress that, the undesirable features derived from the abolition of unanimity in 1945 by the United Nations are less in evidence in the ILO Conventions. The ILO system was partially extended to certain of Specialized Agencies, notably United Nations Educational, Scientific and Cultural Organization (UNESCO), Food and Agriculture Organization (FAO), World Health Organization (WHO) and International Civil Aviation Organization (ICAO), which has permitted them a more satisfactory progress at the technical, legal and functional level ${ }^{40}$.

In accordance with Article 28 of the Rules applicable to the Governing Body of the International Labour Office, the agenda of each session is determined by a tripartite screening group, which will take the decisions, to the extent possible, by consensus. If there is no consensus, the issue will be referred to the Officers.

The ILO understands consensus as the following:

“... The term 'consensus' refers to an established practice under which every effort is made to reach without vote an agreement that is generally accepted.

\footnotetext{
${ }^{38}$ Movsisyan M., Decision Making by Consensus in International Organizations as a Form of Negotiation, 1(3) 21-ST CENTURY 78.

${ }^{39}$ Rosenne SH., United Nations Treaty Practice, 86(II) ReCuEIL Des Cours 313 (1954).

${ }^{40}$ Rosenne SH., op. cit. 39, 315.
} 


\section{THE SEARCH FOR CONSENSUS AND UNANIMITY65}

Those dissenting from the general trend are prepared simply to make their position or reservations known and placed on the record ...."41.

The rule of consensus is also applied in the procedure for the elaboration, examination, adoption and follow-up of declarations, charters and similar standard-setting instruments adopted by the General Conference of UNESCO. In particular, stage 3 indicates that, "the declaration, charter or similar standard-setting instrument shall be adopted by a resolution of the General Conference. Every effort shall be made to adopt the declaration, charter or similar standard-setting instrument by consensus" ${ }^{, 2}$.

A "good example" of consensus is the recent adoption by 195 States of the Paris Agreement in the context of the 2015 United Nations Climate Change Conference, COP 21 held in Paris (France), from November 30 to December 12, 2015. With the following words pronounced by Laurent Fabius, Minister of Foreign Affairs of France "I do not see any objection in the room, I declare the Paris Agreement on Climate Change adopted", consensus was achieved by all States.

The feminist and anti-nuclear movements of the 1970s are often credited with the pioneering of consensus as many activists know it today. Ethan Mitchell cites 4 US-based organisations - the Federation of International Communities, the American Friends' Service Committee, the Clamshell Alliance and Food Not Bombs ${ }^{43}$.

The consensus process has also been used within political movements, non-profit organizations, intentional communities and worker cooperatives. Recently, consensus decision-making is being embraced by government entities and corporations (i.e. Mitsubishi, Levi Strauss \& Co., and Starbucks) ${ }^{44}$.

\section{CONCLUSION}

The roots of the consensus decision making process can be found in the three main religions (i.e. Christian, Muslim and Jewish) and indigenous peoples. The Haudenosaunee Confederacy, the Hanseatic League and Bushmen have all decisively shaped some legal systems, namely the United States of America and European Union and still continue influencing in many African countries.

Additionally, the League of Nations stipulated in Article 5 of its

\footnotetext{
${ }^{41}$ Article 46, Rules Applicable to the Governing Body of the International Labour Office, (Geneva: International Labour Organization 2001).

${ }^{42}$ Adopted by the General Conference at its 33rd session, 33 C/Resolutions, 141-2.

${ }^{43}$ Op. cit. 3.

${ }^{44}$ Op. cit. 3.
} 
Covenant the unanimity rule for all decisions of the Council or Assembly except as otherwise expressly provided in the Covenant. The Permanent Court of International Justice concluded that, resolutions or instruments on questions affecting the well-being of humankind as a whole could not be adopted against the will of some other States. Additionally, the President of the Hague Conference for the Codification of International Law stressed in 1930 that, the international community should adopt unanimous resolutions and that unless we do so, we cannot have any codification of international law.

Despite abolishing the unanimity rule in 1945, the adoption of resolutions by consensus has continued to be the clear tendency and practice at the United Nations since its inception. In 1974, the Director of the General Legal Division at the Office of UN Legal Affairs concluded that, every effort should be made to achieve a consensus before a vote and that, this term was used to describe a practice under which all efforts are made to achieve unanimous agreements.

Because of the inability of the United Nations to find a solution to some conflicts and problems, there has been a common perception that, States are divided in the main UN bodies, namely the Security Council, the General Assembly or the Human Rights Council. However, looking at decisions adopted, the United Nations is actually divided on just a limited number of issues and otherwise largely operates by consensus. In particular, most of the Declarations on peace matters and human rights adopted by the General Assembly since 1945 have always been adopted by consensus.

Finally, important intergovernmental organizations, specialized agencies and social movements have expressly accepted consensus in their respective rules of procedures and have also concluded that, the term "consensus" refers to an established practice under which every effort is made to reach without vote an agreement that is generally accepted.

In conclusion, the consensus system assures that, decision-making regarding a legal instrument recognize the differences among nations and also permits the maintenance of an egalitarian procedure which in practice may assure that, multilateral negotiations reflect the real geopolitical power of all participating nations. 